\title{
An integrated water resources management strategy for Al-Ain City, United Arab Emirates
}

\author{
MOHAMED MOSTAFA MOHAMED \\ Department of Civil and Environmental Engineering, United Arab Emirates University, Al-Ain, PO Box 15551, UAE \\ m.mohamed@uaeu.ac.ae
}

\begin{abstract}
Al-Ain is the second largest city in the Emirate of Abu Dhabi and the third in the UAE. Currently, desalination plants are the only source of drinking water in the city with an average daily supply of 170 MIG. Recently, Abu Dhabi Urban Planning Council (UPC) released Al-Ain 2030 Plan. Projects suggested in this plan, over and above the expected natural population growth, will certainly put additional stress on the water resources in the city. Therefore, Al-Ain city seems to be in urgent need for an integrated water resources management strategy towards achieving sustainable development. This strategy will contain three main components; namely, a Water Demand Forecasting Model (WDFM), a Water Budget Model (WBM), and a Water Resources Optimization Model (WROM). The main aim of this paper is to present the WBM that estimates all inflows and outflows to assess water resources sustainability in the city.
\end{abstract}

Key words integrated water resources; management; water budget; United Arab Emirates

\section{INTRODUCTION}

The Abu Dhabi Emirate is one of the seven Emirates which comprise the United Arab Emirates (UAE) and occupies an area of $67340 \mathrm{~km}^{2}$ or about $80 \%$ of the total area of the UAE (Fig. 1). The Emirate has an arid climate with less than $100 \mathrm{~mm} /$ year average rainfall, a very high evaporation rate $(2-3 \mathrm{~m} /$ year $)$, a low groundwater recharge rate $(<4 \%$ of total annual water used) and no reliable surface water resources (Brook et al. 2006). Furthermore, it is a downstream water user and shares trans-boundary water resources along common borders with Saudi Arabia and the Sultanate of Oman (Brook et al. 2006). The rapid economic development and sharp population increases that occurred over the last couple of decades have resulted in an increasing reliance on unconventional water resources such as desalination. This has also led to the development of alternative conventional water supply measures such as recharge dams, storage dams, and recharge wells. Groundwater is the only conventional source of water in the Emirate of Abu Dhabi. Its share to the total freshwater supply is about $80 \%$. Other unconventional sources of freshwater are desalination plants $(17 \%)$ and wastewater re-use (3\%). Water is consumed in the domestic, industrial, commercial, agricultural, forestry and amenity sectors. With usage of $58 \%$ of total water production, the largest water user is the agricultural sector. Water of drinking quality is supplied for domestic, industrial and commercial use and accounts for about $17 \%$ of the total water consumed. The current share of groundwater is estimated based on the estimated water demand in the Emirate and available production of the desalination plants. The sustainable yield of a groundwater aquifer, however, depends mainly on how fast this aquifer is replenished. Yet, the continuously increasing demand puts more pressure on this already scarce source and threatens its quality. Therefore, for better management of national water resources and to attain security in the vital groundwater source, it is essential to accurately estimate replenishment rates of groundwater.

Accurate estimation of these recharge rates cannot be separated from the recent practice of using desalinated water for irrigation in private farms in the study area. This practice was a consequence of two factors. The first was the justified hindrance policy of groundwater usage for irrigation adapted recently by the authorities in an attempt to recover the overexploited groundwater storage. The second is the hesitancy of individuals to use treated wastewater in irrigation for different valid social concerns. The surplus of treated wastewater is, hence, dumped in desert lagoons imposing additional input to the groundwater storage. Both factors contributed to the immense use of desalinated water in irrigation, which eventually reaches groundwater as another new input to the aquifer. This shift in water resources production and use in the past few years has actually resulted in huge fluctuations in the water table to the extent that groundwater level has surprisingly risen considerably in some areas in Al-Ain. In addition to the abovementioned factors, this rise could be 
related to several other factors including the increase in farm areas and the increase of landscaping due to the rapid urbanization in the last few years. Such urbanization could affect the local hydrological cycle leading to changes in groundwater recharge and discharge rates. The consequences of this problem could range from immediate threats such as flooding of house basements, deterioration of roads, land subsidence causing soils collapse, and damage to building foundations and structures due to settlements, and to long-term environmental threats such as contamination of soils and groundwater, which could lead to complications to human health.

\section{BACKGROUND}

The concept of Integrated Water Resources Management (IWRM) has been promoted recently to improve operating water resources systems. Although the concept itself is generally well established, its implementation is fraught with difficulties because of the inherently complex nature of water resources systems. This is because these systems include not only technical and scientific elements, but also economic, social, and political elements which are equally important. Therefore, in order to reach a robust integration among all these elements, the management strategy must be multidisciplinary to account for all these aspects related to the water system under consideration (Khan 2012, Wood 2012).

The water budget is an important tool that is used to describe the water hydrologic cycle by summation of inputs and outputs of water resources through a study area over a fixed period of time. The hydrological system in any study area is governed by the mass conservation law (Fig. 2). In other words, the rise and drop of water table depends on the difference between total water inputs and total water output from the system. For a specific control volume (study area) within a certain time, if a total input is less than the total output, the water table will decline in the aquifer. However, if the total input exceeds the total output, the aquifer will undergo a net recharge. In general, there are several components of a water budget. Inputs include precipitation, runoff, groundwater inflow, surface water inflow, and water diversions. While outputs include evaporation, transpiration, groundwater outflow, surface water outflow, irrigation, industrial uses, residential uses, and water diversions.

\section{HYDROGEOLOGICAL SETTINGS OF THE STUDY AREA}

The main aquifers in the Abu Dhabi Emirate are widespread and around $80 \%$ of the territory comprises Quaternary sand, or sand and gravel aquifers. Groundwater flow systems in Abu Dhabi are controlled by recharge processes, the geology of the host rocks, and the residence time of

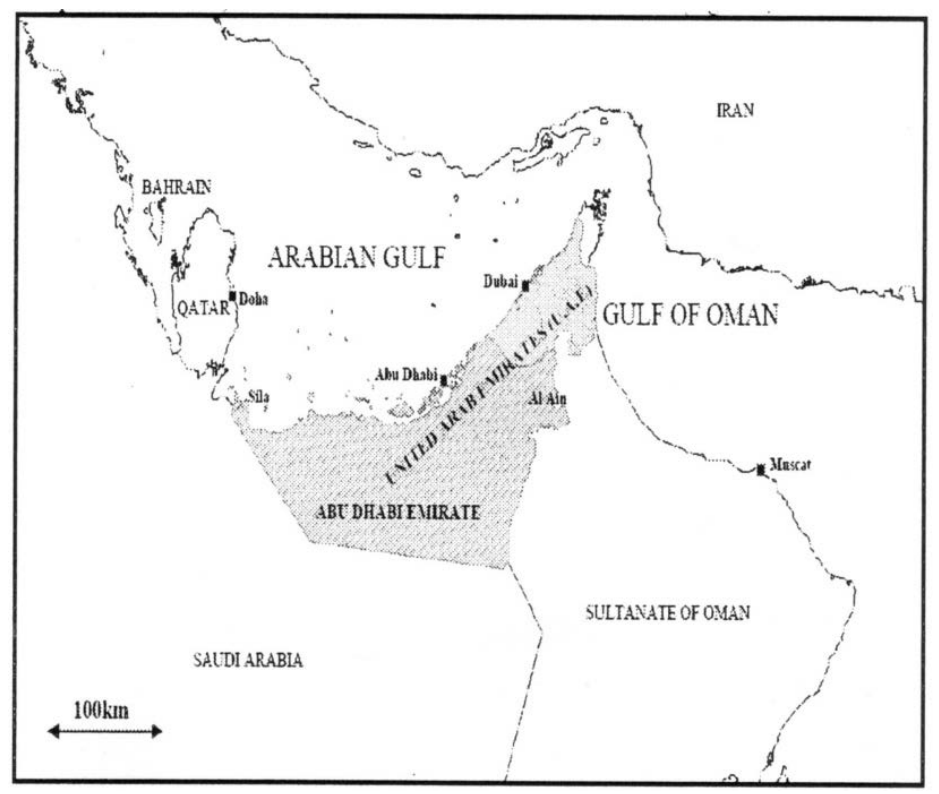

Fig. 1 Location map of Al-Ain City. 


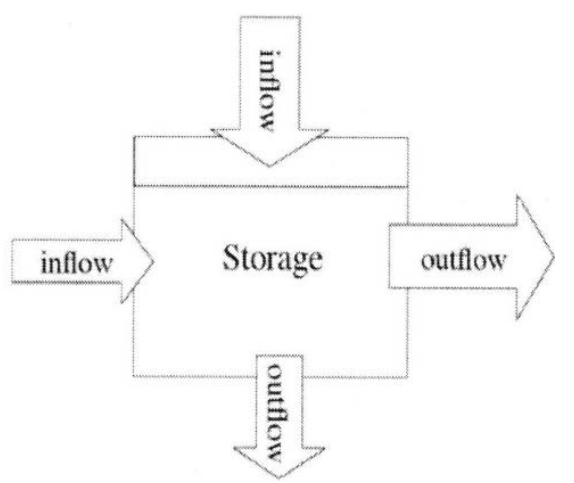

Fig. 2 Water budget diagram.

groundwater and discharge processes. The main recharge mechanisms are: (1) infiltration of periodic surface flow along wadis that drain the Oman Mountains, (2) subsurface flow from lateral flow in alluvial channels at the mouths of the drainage basins (gaps) along the mountain front, and (3) lateral flow through fractured bedrock along the mountain front (Imes et al. 1993, Bright et al. 1996). These three recharge mechanisms create three types of flow systems that occur within the Emirate (local, intermediate, and regional), based on hydrological, hydrochemical and isotopic characteristics of groundwater (Fig. 3). Groundwater movement is generally from East to West for all three flow types. Flow times from recharge zones in the East to the sabkha discharge zones along the Gulf coastline can take up to 15000 years (Alsharhan 2001). This slow groundwater movement allows for considerable dissolution of salts in the groundwater and the longer the residence time, the higher the salt content; hyper-saline waters in excess of $200000 \mathrm{mg} / \mathrm{L}$ are found along the Abu Dhabi coastline (Brook et al. 2006).

Unconsolidated aquifers are the most common and productive aquifers in Abu Dhabi and comprise both recent sand dunes and alluvial deposits of varying age. The deposits comprise the surficial unconfined aquifers of Abu Dhabi Emirate, the top of which is defined by the water table. Symonds et al. (2005) classified the surficial geology of Abu Dhabi Emirate into (1) the coastal regions of tidal flats, sabkhas, and terraces, along the Arabian Gulf, (2) the internal sand-dune region covering most of the Emirate, and (3) the piedmont plain in the eastern part. According to GTZ (2005), the "shallow aquifer comprises all permeable layers that are hydraulically connected and exhibit a hydraulic head that is defined by the water table for any given point"; the upper aquifer comprises the upper part to the shallow aquifer which is generally hydraulically more active when yielding groundwater to a fully penetrating well; the lower part of the shallow aquifer can therefore often be considered an aquitard. The average thickness of the Quaternary alluvium in the study area is about $30 \mathrm{~m}$, the specific yield is estimated to be about 10 to $15 \%$, and the average transmissivity of the surficial aquifer is about $270 \mathrm{~m}^{2} / \mathrm{d}$ (Symonds et al. 2005). Aquifer transmissivity in the north is larger than in the Al-Ain Area near Jabal Hafit (Bright et al. 1996).

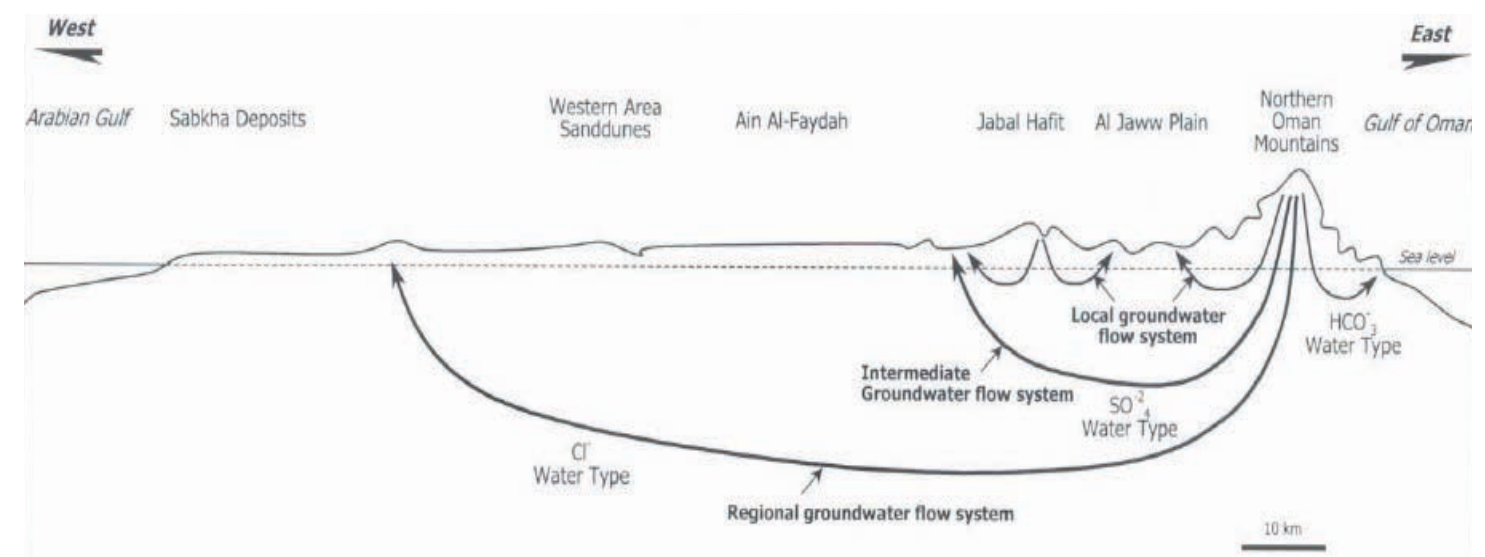

Fig. 3 Regional groundwater systems in Abu Dhabi (Alsharhan 2001). 


\section{WATER BUDGET MODEL}

Components of the designed water budget model for the surficial aquifer in the eastern district in Abu Dhabi Emirate are illustrated in Fig. 4. The study area receives desalinated water (DW in Fig. 4) from several desalination plants. This water is distributed to the different water use sectors in the Al-Ain city through Al-Ain Distribution Company (AADC). During this process, some of this water is leaked (L in Fig. 4) into the surficial aquifer. People at home use some of the distributed water to irrigate (IR) farms and small gardens. The amount of this water used in irrigation has not been estimated before. One objective of this budget model is to estimate this amount. Water used in the different use sectors is then transferred to the wastewater treatment plants (WWTP) in Al-Ain. The treated sewage effluent (TSE) from the WWTP is used in the irrigation (TSEIR) of public parks and landscaping in Al-Ain. Another part is disposed of into surface lagoons that eventually recharge (R) the surficial aquifer of Al-Ain. Another possible input to the system is the deep well pumping (DWP) from deep aquifers below the surficial aquifer that is used for irrigation and eventually recharge the surficial aquifer. Possible outputs from the system under consideration in this water budget model are the evapotranspiration (ET) and groundwater outflow towards the central and western parts of Abu Dhabi Emirate.

\section{Input Flows}

Desalinated water (DW) Most of the people in Al-Ain area receive their water through the distribution network, but a small fraction receives water by tankers. Not all residents connected to the network have installed water meters. For example, the total number of customers (connected to the network) at AADC is 62000 . These customers cover different activities, including residential, commercial, agriculture, etc. Of these, 26000 customers are classified as residential with meters and 15000 as residential without meters. Of the 26000 metered residential customers, 11700 are expatriates and the rest are nationals. Currently, about 600000 cubic metres of desalinated water is distributed daily (AADC personal communication 2012). Therefore, the total annual volume of desalinated water distributed in Al-Ain is estimated to be $219 \times 10^{6} \mathrm{~m}^{3} /$ year. Almost $50 \%$ of this water is distributed for domestic use (D); while the other $50 \%$ is distributed for other uses (commercial (C), industrial (I), and agricultural (A) use). The water used in commercial and industrial use will eventually be received by the WWTP. The agricultural water use, also accounted for in the water budget model under IR (Fig. 4) will then enter the surficial aquifer directly.

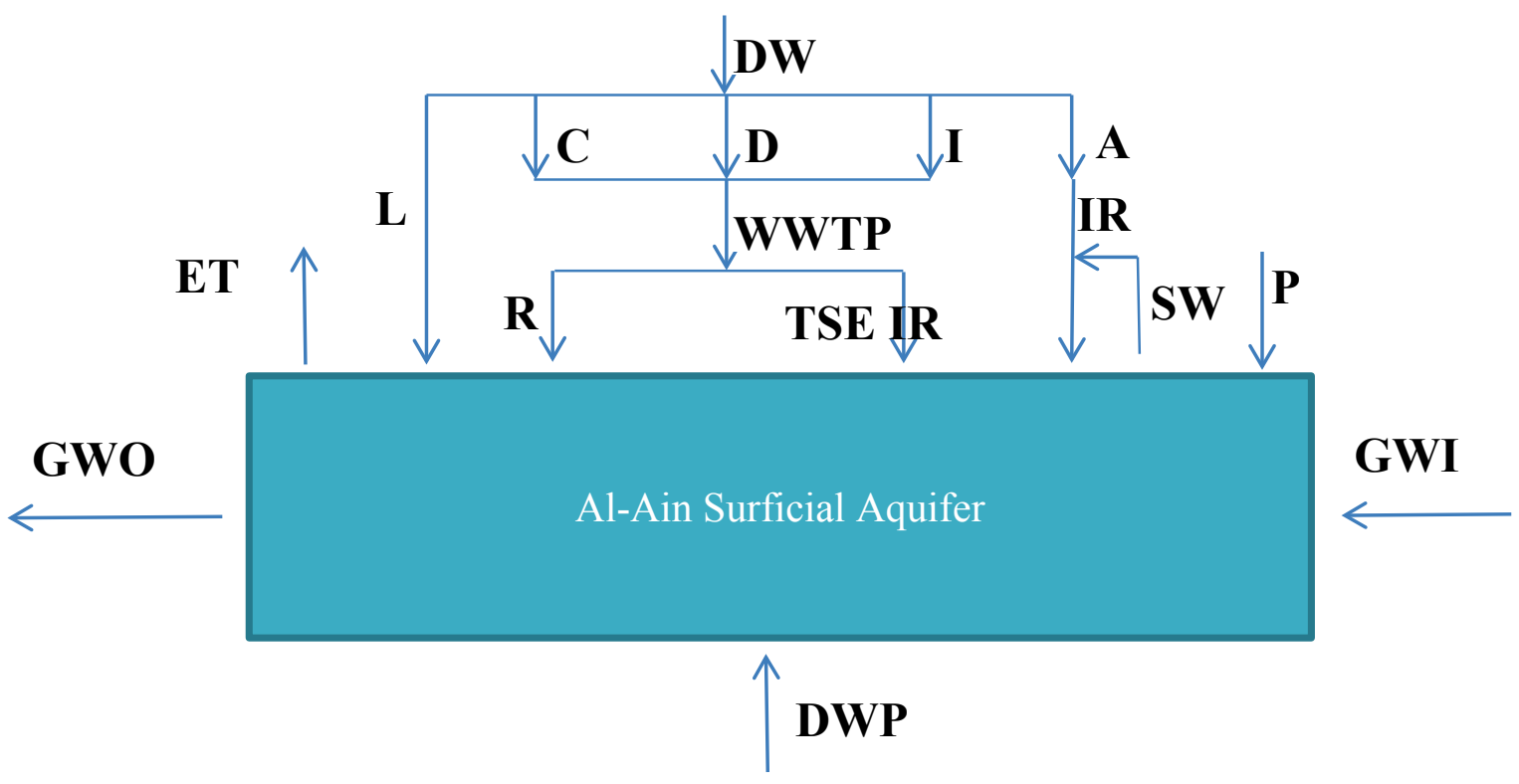

Fig. 4 Water budget model components. 
Leakage from distribution network (L) The Leakage from the distribution system is estimated to be $10 \%$ of the total distributed amount of water. This is estimated as $21.9 \times 10^{6} \mathrm{~m}^{3} /$ year.

Precipitation (P) Al Ain is located in an arid zone with an average precipitation of $100 \mathrm{~mm} /$ year (Brook et al. 2006). The surface area of the study area is estimated to be $25 \times 40=1000 \mathrm{~km}^{2}$. This area is expected to have received $100 \times 10^{6} \mathrm{~m}^{3} /$ year.

Groundwater inflow from Omani Mountains (GWI) The topography of the area between Al Ain and Oman is mainly mountains that shape many wadis. These wadis discharge into Al-Ain. The characteristics of these wadis are steep and active after heavy rainfall, but after crossing the Emirati borders the velocities of the flow are reduced a lot due to the flatter topography of the area (Brook et al. 2006). Groundwater inflow from Oman is calculated using Darcy's Law:

$\mathrm{Q}=\mathrm{K}$ A I

where $\mathrm{K}$ in the eastern part of Abu Dhabi Emirate equals $1 \times 10^{-5} \mathrm{~m} / \mathrm{s}$ (Alhammadi 2003, Al Shahi 2002), the average aquifer depth is $15 \mathrm{~m}$ (Brook et al. 2006), length of study area is $25 \mathrm{~km}$; the hydraulic gradient $(\mathrm{I}=\Delta \mathrm{H} / \Delta \mathrm{L})$ in the study area is calculated using head contours presented in Brook et al. 2006 for $\Delta \mathrm{H}=20 \mathrm{~m}$ and $\Delta \mathrm{L}=4000 \mathrm{~m}, \mathrm{I}=5 \mathrm{~m} / \mathrm{km}$. Substituting into the Darcy equation, the obtained value of groundwater inflow is $0.6 \times 10^{6} \mathrm{~m}^{3} /$ year.

\section{Inputs to the WWTPs}

The two main wastewater treatment plants (WWTP) in the area are Zakher and Al Saad plants. They have a role in recharging Al-Ain aquifers as the treated wastewater is used in the irrigation of public parks and landscapes in Al-Ain. The design capacity of Zakher plant is $54000 \mathrm{~m}^{3} /$ day; however, with the increase of public water use the plant's capacity was increased to $85000 \mathrm{~m}^{3} /$ day to accommodate the subsequent increase in wastewater. The actual amount of water received by the plant on an average daily basis is $80000 \mathrm{~m}^{3} /$ day and all received water is treated and re-used in irrigation (ADSSC 2012). According to ADSSC, the AlSaad plant has a capacity of $90000 \mathrm{~m}^{3} /$ day, and the actual amount of the water received is $70000 \mathrm{~m}^{3} /$ day. The whole amount of received water is also treated and re-used in irrigation as Zakher plant (ADSSC 2012). The total annual amount of water received by both WWTP is $54.75 \times 10^{6} \mathrm{~m}^{3} /$ year. The amount of water (IR) that is believed to be used in agricultural use and in irrigation of private farms and gardens can then be calculated as IR $=\mathrm{DW}-\mathrm{L}-\mathrm{WWTP}$. This amount is estimated to be $142.35 \times 10^{6} \mathrm{~m}^{3} /$ year. It must be mentioned here that few inhabitants in Al-Ain use pumped water from shallow wells (SW) for irrigation. This amount is not estimated as it will not affect water storage in the unconfined aquifer.

Treated sewerage effluent in irrigation and recharge (TSEIR \& $\mathbf{R}$ ) Reports by ADSSC show that the treated sewerage is either re-used for irrigation of public parks and landscaping (TSEIR) or disposed of to surface ponds (R). It is estimated that the average amount sent to these ponds (R) is about $10 \%$ of the total TSE; about $5.5 \times 10^{6} \mathrm{~m}^{3} /$ year, leaving TSEIR to be about 49.0 $\times 10^{6} \mathrm{~m}^{3} /$ year.

Deep wells pumping (DWP) Although many of the deep wells in Al-Ain are not in operation, few are still used for irrigation. Groundwater from the deep aquifer is pumped through these wells and ultimately recharges the surficial aquifer through irrigation, creating another input source for the surficial aquifer. It is estimated that $20 \%$ of the total water demand for irrigation originates from deep wells. This is calculated to be about $35.5 \times 10^{6} \mathrm{~m}^{3} /$ year.

\section{Output flows}

Groundwater outflow (GWO) Groundwater outflow is calculated using Darcy's law. However, a different value is used for $\mathrm{K}$ in the western part of AlAin that equals $5 \times 10^{-6} \mathrm{~m} / \mathrm{s}$ (Alhammadi 2003), the average aquifer depth is $25 \mathrm{~m}$ (Brook et al. 2006), length of study area is 25 $\mathrm{km}$; the hydraulic gradient $(\mathrm{I}=\Delta \mathrm{H} / \Delta \mathrm{L})$ in the study area is calculated using head contours presented in Brook et al. 2006 for $\Delta \mathrm{H}=20 \mathrm{~m}$ and $\Delta \mathrm{L}=2500 \mathrm{~m}, \mathrm{I}=8 \mathrm{~m} / \mathrm{km}$. Substituting into Darcy's equation, the obtained value of groundwater inflow is $0.79 \times 10^{6} \mathrm{~m}^{3} /$ year. 
Evapotranspiration (ET) The average evapotranspiration rate in Al-Ain is about $2.5 \mathrm{~m} / \mathrm{year}$ (Brook et al. 2006). The total irrigated area in Al-Ain is estimated to be about $70 \mathrm{~km}^{2}$ (GTZ 2008). Then, the total volume of evapotranspiration is estimated to be $175 \times 10^{6} \mathrm{~m}^{3} /$ year. All the calculated inputs and outputs are summarized in Table 1.

Table 1 Inflows and outflows $\left(10^{6} \mathrm{~m}^{3} /\right.$ year $)$ from $\mathrm{Al}$ Ain aquifers.

\begin{tabular}{|c|c|c|c|c|c|c|c|c|c|c|c|}
\hline \multirow[b]{2}{*}{ GWI } & \multirow[b]{2}{*}{$\mathrm{P}$} & \multicolumn{3}{|c|}{ INFLOW } & \multirow[b]{2}{*}{$\mathrm{L}$} & \multirow[b]{2}{*}{ DWP } & \multirow{2}{*}{$\begin{array}{l}\text { Total } \\
\text { Input }\end{array}$} & \multicolumn{2}{|c|}{ OUTFLOW } & \multirow{2}{*}{$\begin{array}{l}\text { Total } \\
\text { Output }\end{array}$} & \multirow[t]{2}{*}{ Balance } \\
\hline & & IRR & TSEIR & $\mathrm{R}$ & & & & ET & GWO & & \\
\hline 0.6 & 100 & 142.4 & 49 & 5.5 & 21.9 & 35.5 & 354.9 & 175 & 0.8 & 175.8 & 179.1 \\
\hline
\end{tabular}

\section{SUMMARY AND CONCLUSIONS}

In this paper, a simple hydrological budget model was developed to estimate the groundwater recharge in Al-Ain area of UAE in the year 2012. The control volume selected for this model is the surficial unconfined aquifer in the eastern part of the Abu Dhabi Emirate. A detailed conceptual model representing all potential inflows such as precipitation, recharge from treated sewage effluents ponds, surface flow, irrigation returns, and subsurface inflow; and outflows such as evapotranspiration and subsurface outflow, was developed. This model used input parameters that are readily available or obtainable. It was found that the input flow is almost double the output flow. This might explain the recent groundwater rise that is experienced in different areas in Al Ain. This unaccounted difference could be traced back to several sources such as the use of drinking water in irrigation in some farms or the leakage from the water distribution network. A more detailed study will be conducted to assess the water balance in Al-Ain surficial aquifer over a longer period for better management of the water resources in this area.

Acknowledgement This research was funded by the UAE National Research Foundation (NRF) and the UAE University (projects' numbers UIRCA-2012-21806 and UAEU-31N098). The authors acknowledge the assistance provided by both institutes. The author would like to acknowledge the help of Al Ain Distribution Company (AADC) for providing some of the data used to develop this model.

\section{REFERENCES}

Al Hammadi Muna, K. (2003) Assessment of Groundwater Resources using Remote Sensing and GIS. Master of Science in Water Resources. Faculty of Graduate Studies United Arab Emirates University. June, 2003.

Al Shahi, Fatma A. (2002) Assessment of Groundwater Resources in Selected Areas of Al Ain in the U.A.E. Master of Science in Water Resources. Faculty of Graduate Studies United Arab Emirates University. December, 2002.

Alsharhan, A. S. (2001) Hydrogeology of an Arid Region: The Arabian Gulf and Adjoining Areas. Elsevier, New York.

Bright, D. J., Tamayo, J. M. and Khalifa, M. A. (1996) Ground-water conditions in Abu Dhabi Emirate; pt. v in Hutchinson, C.B., ed., 1996, Ground-water resources of Abu Dhabi Emirate: US Geological Survey Administrative Report, p. 62-107, prepared for the National Drilling Company, Abu Dhabi.

Brook, M. C., et al. (2006) Groundwater Resources; Development and Management in Abu Dhabi Emirate, UAE. In: Proceedings of 3rd Joint UAE-Japan Symposium, Sustainable GCC Environment and Water Resources, EWR, 2006.

GTZ/Dornier Consult/ADNOC (2005) Combined artificial recharge and utilization of the groundwater resource in the Greater Liwa Area. Pilot Project Final Technical Report.

Imes, J. L., Signor, D. C. and Woodward, D. G. (1993) Hydrology and water quality. In: Groundwater Resources of Al Ain area, Abu Dhabi Emirate (ed. by D. V. Maddy). US Geological Survey Administrative Report 93-1, prepared for the National Drilling Company, Abu Dhabi, UAE, pp. 168-283.

Khan, S. (2012) Changing physical and social environment: hydrologic impacts and feedbacks: Introduction to special issue. J. Hydrol. 412-413, 1-2.

Rizk, Z. S, Garamoon, H. K. and El Etr, H. A. (1998) Morphometry, surface runoff and flood potential of major drainage basins of Al Ain area, United Arab Emirates. Egypt. Journal of Remote Sensing \& Space Sciences 1, $391-412$.

Symonds, R. B., Robledo A. R. and Al Shateri, H. A. (2005) Use of environmental tracers to identify and date recent recharge to the surficial aquifer of northeastern Abu Dhabi Emirate, United Arab Emirates Pg 471-486 in conference proceedings Vol 1 - WSTA Seventh Gulf Water Conference - Water in the GCC - Towards and Integrated Management - 19-23 November, State of Kuwait.

Wood, W. W. (2012) Reductionism to integrationism: a paradigm shift. Ground Water 50(2), 167. 